\title{
Program profilaktyki nadwagi i otyłości Odważna Ósemka jako element polityki zdrowotnej Szczecina
}

\author{
The Brave Eight Programme for the prevention of overweight and obesity as part of the health \\ policy in the city of Szczecin
}

\author{
Marcin Kolwitz ${ }^{凶}$ \\ Pomorski Uniwersytet Medyczny w Szczecinie, Zakład Medycyny Społecznej i Zdrowia Publicznego, ul. Żołnierska 48, 71-210 Szczecin \\ Pomeranian Medical University in Szczecin, Department of Social Medicine and Public Health \\ $\triangle$ rutinex@pum.edu.pl
}

\begin{abstract}
Prevention and health promotion programmes are instruments of health policy implemented by local government. Health policy is in turn an element of social policy. The strategy for solving social problems for the municipality of the city of Szczecin in Poland for the years 2015-2020 is a key document defining the goals of social policy for the city of Szczecin. Szczecin authorities are currently implementing the programme „Prevention of overweight and obesity among 8-year-old children attending primary schools in Szczecin", called the Obesity Prevention Programme - the Brave Eight. It addresses the health hazards emerging in pre-school
\end{abstract}

\begin{abstract}
ABSTRAKT
Programy profilaktyki i promocji zdrowia są instrumentem polityki zdrowotnej realizowanej przez samorząd terytorialny. Polityka zdrowotna jest z kolei elementem polityki społecznej. Strategia Rozwiązywania Problemów Społecznych dla Gminy Miasto Szczecin na lata 2015-2020 jest kluczowym dokumentem określającym założenia polityki społecznej dla miasta Szczecina. Aktualnie realizowanym w Szczecinie programem jest „Przeciwdziałanie nadwadze i otyłości wśród dzieci w wieku 8 lat uczęszczających do szczecińskich szkół podstawowych". Został on nazwany Programem Zapobiegania Otyłości - Odważna
\end{abstract}

and early childhood: overweight and obesity. Measures under the Brave Eight programme aim to identify the population at risk by screening and changing the health behaviour of children (modifying eating habits and promoting physical activity). The programme received a positive review from Agencja Oceny Technologii Medycznych i Taryfikacji (Agency for the Assessment of Medical Technology and Tariffs), and its implementation began in September 2016.

Keywords: health policy programme; health promotion; obesity; the city of Szczecin; local government.

\section{STRATEGIA ROZWIAZYWANIA PROBLEMÓW SPOEECZNYCH}

Strategia Rozwiązywania Problemów Społecznych dla Gminy Miasto Szczecin na lata 2015-2020 jest kluczowym dokumentem określającym założenia polityki społecznej dla Szczecina. Została on przyjęta Uchwałą Rady Miasta 23 lutego 2016 r. [1].

Miasto Szczecin, będące jednocześnie gminą miejską i miastem na prawach powiatu, wykonuje zadania z zakresu polityki społecznej i zdrowotnej należące do obu jednostek samorządowych. Opracowanie strategii jest obowiązkiem dla jednostek samorządu terytorialnego i wynika z ustaw: z dnia 5 czerwca 1998 r. o samorządzie powiatowym [2], z dnia 8 marca 1990 r. o samorządzie gminnym [3] oraz art. 17, ust. 1, pkt 1 i art. 19,
Ósemka. Odpowiada na zagrożenia zdrowotne pojawiające się w wieku przedszkolnym i wczesnoszkolnym - nadwagę i otyłość. Działania związane z programem Odważna Ósemka mają na celu wyodrębnienie populacji dotkniętej i zagrożonej problemem (badania przesiewowe) oraz zmianę zachowań zdrowotnych wśród dzieci (zmiana nawyków żywieniowych oraz promowanie aktywności fizycznej). Projekt programu został oceniony pozytywnie przez Agencję Oceny Technologii Medycznych i Taryfikacji i we wrześniu 2016 r. rozpoczęła się jego realizacja.

Słowa kluczowe: program polityki zdrowotnej; promocja zdrowia; otyłość; miasto Szczecin; samorząd terytorialny.

pkt 1, w powiązaniu z art. 16b ustawy z dnia 12 marca $2004 \mathrm{r}$. o pomocy społecznej [4].

W ramach zadań własnych samorządu ustawy te przewidują „opracowanie i realizację Gminnej Strategii Rozwiązywania Problemów Społecznych ze szczególnym uwzględnieniem programów pomocy społecznej, profilaktyki i rozwiązywania problemów alkoholowych i innych, których celem jest integracja osób i rodzin z grup szczególnego ryzyka” - na poziomie gminy oraz „opracowanie i realizacja powiatowej strategii rozwiązywania problemów społecznych, ze szczególnym uwzględnieniem programów pomocy społecznej, wspierania osób niepełnosprawnych i innych, których celem jest integracja osób i rodzin z grup szczególnego ryzyka po konsultacji z właściwymi terytorialnie gminami" - na poziomie powiatu. 
Strategia zawiera zarówno diagnozę, planowanie, wdrażanie, jak i ewaluację działań zmierzających do rozwiązania problemów społecznych. Dokument pełni więc funkcje: decyzyjną, koordynacyjną i informacyjno-edukacyjną. Został opracowany przez Miejski Ośrodek Pomocy Rodzinie (MOPR) i jest wynikiem prac zespołu badawczego, w skład którego weszli przedstawiciele MOPR, Wydziału Spraw Społecznych Urzędu Miasta, Uniwersytetu Szczecińskiego przy wsparciu ekspertów z Pomorskiego Uniwersytetu Medycznego w Szczecinie (PUM) i Uniwersytetu Szczecińskiego.

Zasadnicze działania z zakresu polityki społecznej (w tym także zdrowotnej), zapisane w dokumencie, mieszczą się w dwóch obszarach:

Pierwszy obszar - Profilaktyka dla dzieci i udogodnienia dla rodziców - to:

1. Zdrowie dzieci (programy profilaktyki i promocji zdrowia).

2. Szkoła rodziców (szkolenia i edukacja osób dorosłych).

3. Szczecin Przyjazny Rodzinie (kontynuacja i rozwój programu).

4. Zwiększenie liczby miejsc w opiece żłobkowej.

Drugi obszar - Senior w mieście - to:

1. Centrum Informacji Senioralnej i system domów pomocy społecznej.

2. Oddawanie do użytku kolejnych mieszkań chronionych i tworzenie rodzinnych domów pomocy.

3. Usankcjonowanie pomocy sąsiedzkiej.

4. Dzienne formy wsparcia seniora [1].

Strategia Rozwiązywania Problemów Społecznych dla Gminy Miasto Szczecin na lata 2015-2020 jest uważana za kontynuację wcześniejszej Strategii z lat 2009-2015. Opiera się ona w znacznej mierze na innych dokumentach dotyczących polityki społecznej i jest z nimi spójna. Pierwszy dokument to program rozwoju miasta Szczecina 2020 poddany przez prezydenta miasta pod konsultacje społeczne w marcu 2014 r. [5]. Drugi to tzw. Drugie Porozumienie Programowe dla miasta Szczecina podpisane w grudniu 2014 r. i określające priorytety na lata 2014-2020 w zakresie polityki społecznej. Radni i Prezydent Miasta zobowiązują się w tym dokumencie do podejmowania działań w zakresie czterech priorytetów: Praca, Edukacja, Otoczenie, Współdecydowanie (zostały one już zapisane w programie Szczecin 2020) [6].

Programy polityki zdrowotnej mieszczą się w ramach priorytetu dotyczącego Otoczenia, obejmującego odpowiedzialność społeczną i zawierającego projekt Zdrowie Naszych Dzieci. Realizacja tego projektu obejmuje wprowadzenie programów dotyczących: przeciwdziałania otyłości, profilaktyki stomatologicznej, badań profilaktycznych wzroku oraz wad postawy. Oprócz przedsięwzięcia Zdrowie Naszych Dzieci w ramach obszaru Otoczenie - odpowiedzialność społeczna mieszczą się też m.in. projekty z zakresu polityki prorodzinnej - Szczecin przyjazny rodzinie i polityki senioralnej - akcja „Senior w mieście" [5, 6].

Fakt, że wpływ na powstanie zarówno Strategii 2015-2020, jak i poprzedzających ją dokumentów miały różne podmioty, instytucje powołane do realizacji zadań z zakresu polityki społecznej, inne instytucje publiczne, jednostki lokalne (rady osiedli), organizacje trzeciego sektora, a także świadczeniobiorcy, czyli mieszkańcy miasta, świadczy o wielosektorowości polityki społecznej.

\section{PROGRAMY PROMOCJI ZDROWIA JAKO NARZĘDZIE POLITYKI SPOŁECZNEJ I ZDROWOTNEJ}

Polityka zdrowotna jako polityka szczegółowa i składowa polityki społecznej działa w kierunku zniwelowania nierówności dotyczących stanu zdrowia i dostępu do opieki zdrowotnej. Nierówności te związane są zazwyczaj z różnicami w statusie socjoekonomicznym (wykształcenie, dochody itp. mają wpływ na zdrowie) oraz uwarunkowaniami środowiskowymi i stylem życia.

Polityka zdrowotna odnosi się do decyzji, planów i działań zmierzających do określonych celów [7], a także jest skorelowana z promocją zdrowia, którą można określić - zgodnie z Kartą Ottawską z 1986 r. - jako proces umożliwiający każdemu człowiekowi zwiększenie oddziaływania na własne zdrowie w sensie jego utrzymania i poprawy, co może się dokonać poprzez wdrażanie efektywnych programów, świadczeń i polityk [8].

Promocja zdrowia obejmuje różne etapy działań prozdrowotnych, począwszy od profilaktyki wczesnej, czyli przekazywania informacji o zdrowiu ludzi, odrzucenia bądź likwidacji ekonomicznych, społecznych, kulturowych wzorców i nawyków, które bezpośrednio lub pośrednio powodują wzrost zagrożeń zdrowia. Kolejnymi etapami są profilaktyka pierwotna, czyli zmniejszenie częstości zachorowań poprzez ograniczenie ryzyka powstania choroby, oraz profilaktyka pośrednia, czyli zmniejszenie rozprzestrzeniania się chorób poprzez skracanie czasu ich trwania. Ostatni etap to profilaktyka wtórna zmniejszenie liczby chorych poprzez ograniczanie następstw choroby [9]. Nieodłączną częścią promocji zdrowia jest więc zarówno profilaktyka (zapobieganie chorobom), edukacja zdrowotna (dostarczająca wiedzy i zmierzająca do zmiany określonych zachowań), jak i lokalna polityka zdrowotna [10].

Instrumentem lokalnej polityki zdrowotnej są programy promocji zdrowia i profilaktyki zdrowia, adresowane do mieszkańców jednostki samorządu terytorialnego. Jako program promocji zdrowia można określić zespół zaplanowanych i zamierzonych działań z zakresu opieki zdrowotnej, ocenianych jako skuteczne, bezpieczne i uzasadnione. Działania te umożliwiają osiągnięcie w określonym terminie założonych celów polegających na wykrywaniu i zrealizowaniu określonych potrzeb zdrowotnych oraz poprawy stanu zdrowia określonej grupy świadczeniobiorców (art. 5, ust. 29a, 30) [11].

Ustawa o świadczeniach opieki zdrowotnej finansowanej ze środków publicznych w art. 5 rozróżnia dwa rodzaje programów. Program polityki zdrowotnej jest opracowany, wdrażany, realizowany i finansowany przez ministra albo jednostkę samorządu terytorialnego, natomiast program zdrowotny przez Narodowy Fundusz Zdrowia (NFZ). 
Ustawa o świadczeniach opieki zdrowotnej finansowanej ze środków publicznych dopuszcza też możliwość realizacji programów polityki zdrowotnej przez NFZ po zleceniu ich przez ministra zdrowia.

Programy polityki zdrowotnej dotyczą zazwyczaj ważnych zjawisk epidemiologicznych (np. tzw. chorób cywilizacyjnych) oraz pozostałych istotnych problemów zdrowotnych dotyczących całej lub określonej grupy świadczeniobiorców, a także wdrożenia nowych procedur medycznych i przedsięwzięć profilaktycznych (art. 48, ust. 3) [11].

Ogólny schemat działania w polityce zdrowotnej, odnoszący się także do programów promocji zdrowia, jest następujący:

1. Analiza sytuacji.

2. Wybór priorytetów.

3. Zdefiniowanie celów i strategii działania.

4. Realizacja ustalonych działań.

5. Ewaluacja efektów działań [12].

\section{TWORZENIE PROGRAMÓW POLITYKI ZDROWOTNEJ}

Przy tworzeniu programów polityki zdrowotnej niezbędne jest określenie problemów zdrowotnych istotnych dla danej społeczności i celów zdrowotnych z nimi związanych (zasięg problemu zdrowotnego, a także częstość oraz społeczne i ekonomiczne skutki jego występowania). W związku z tym należy dokonać wyboru populacji objętej działaniem oraz interwencji medycznej, która ma być podjęta. Należy prawidłowo zdefiniować, dokładnie określić i opisać problem, jego przyczyny, znaczenie dla społeczeństwa. Niezbędne jest opracowanie diagnoz związanych z problemem zdrowotnym.

Diagnoza demograficzna zawiera szczegółowy opis populacji, do której program jest adresowany: wiek, płeć, miejsce zamieszkania, stan cywilny, wykształcenie, a także tryb zapraszania do programu i sposób kwalifikacji uczestników. Diagnoza epidemiologiczna uwzględnia najistotniejsze mierniki zdrowia: chorobowość (odsetek chorujących), zapadalność (odsetek nowych zachorowań), śmiertelność (odsetek zgonów wśród chorych), umieralność (odsetek zgonów w określonej populacji). Diagnoza społeczna określa czynniki społeczne wpływające na zdrowie, np. alkoholizm, narkomania, bezrobocie, natomiast behawioralna obejmuje zachowania wpływające na zdrowie - pro- i antyzdrowotne, np. tryb życia.

Kolejnym elementem programu są cele szczegółowe, które wskazują szczegółowy opis działania (w odróżnieniu od celu głównego, który określa ogólne efekty wdrożenia programu). Przy ich ustalaniu stosowane jest tzw. kryterium SMART, które oznacza: S - specyficzność - określenie oczekiwanych rezultatów: redukcja, zmniejszenie, zwiększenie, wyeliminowanie; M - mierzalność - możliwość zmierzenia, obliczenia, określenia wyników; A - aprobata - akceptacja założeń programu przez osoby w nim uczestniczące; R - realność - możliwość osiągnięcia zakładanych celów (w momencie startu powinno być minimum 50\% szans na realizację); T - terminowość - określenie czasu do zrealizowania programu.
Organizacja programu obejmuje m.in. informacje: o planowanych interwencjach, o etapach i sposobie realizacji zadań; o świadczeniach alternatywnych finansowanych ze środków publicznych i o zasadach realizacji świadczeń w ramach programu; o dowodach skuteczności planowanych działań (efektywności klinicznej lub kosztowej). Istotnym etapem konstruowania programu jest stworzenie harmonogramu, czyli graficznego opisu programu obejmującego m.in.: kosztorys (źródła finansowania, całkowite i jednostkowe koszty programu zdrowotnego), kryterium określenia wyników, metody realizacji, termin, wykonawców, środki. Kolejne etapy to: ustalenie budżetu (zasoby ludzkie i rzeczowe, materiały reklamowe, ogólny koszt), określenie podmiotów współpracujących, przygotowanie materiałów informacyjnych. Końcowy etap konstruowania programu obejmuje określenie sposobów monitorowania i ewaluacji programu w zakresie procesu, wyniku i wpływu (zgłaszalność do programu, ocena jakości świadczeń zdrowotnych, ocena efektywności programu - mierniki epidemiologiczne, zmiana zachowań związanych z programem) [8].

\section{PROGRAMY POLITYKI ZDROWOTNEJ REALIZOWANE PRZEZ JEDNOSTKI SAMORZĄDU TERYTORIALNEGO}

Realizacja programów polityki zdrowotnej jest zadaniem władz publicznych (w tym samorządowych), na których spoczywa obowiązek zapewnienia równego dostępu do świadczeń opieki zdrowotnej (art. 6) wynikający z ustawy o świadczeniach opieki zdrowotnej finansowanej ze środków publicznych:

1. Tworzenie warunków funkcjonowania systemu ochrony zdrowia.

2. Analiza i ocena potrzeb zdrowotnych oraz czynników powodujących ich zmiany.

3. Promocja zdrowia i profilaktyka mające na celu tworzenie warunków sprzyjających zdrowiu.

4. Finansowanie w trybie i na zasadach określonych ustawą świadczeń opieki zdrowotnej [11].

Możliwość realizacji zadań z zakresu promocji zdrowia i ochrony zdrowia została zapisana już w ustawach regulujących działanie jednostek samorządu tery torialnego. Ustawa z dnia 8 marca 1990 r. o samorządzie gminnym w art. 7, ust. 1 jako jedno z zadań własnych gminy wymienia ochronę zdrowia [3], natomiast w art. 4, ust. 1, pkt 2 ustawy z dnia 5 czerwca 1998 r. o samorządzie powiatowym zapisano, że powiat wykonuje określone ustawami zadania publiczne o charakterze ponadgminnym w zakresie promocji i ochrony zdrowia [2].

Możliwość finansowania programów polityki zdrowotnej przez gminę i powiat została określona w ustawie z dnia 15 kwietnia 2011 r. o działalności leczniczej. Podmiot wykonujący działalność leczniczą może otrzymać środki publiczne z przeznaczeniem na: realizację zadań w zakresie programów polityki zdrowotnej, programów zdrowotnych i promocji zdrowia, w tym na zakup aparatury i sprzętu medycznego oraz wykonanie innych inwestycji koniecznych do realizacji tych zadań. 
Na realizację zadań podmioty wykonujące działalność leczniczą mogą uzyskać środki finansowe na podstawie umowy zawartej m.in. z jednostką samorządu terytorialnego (art. 114, ust. 1, pkt 1; art. 115, ust. 1, pkt 1) [13].

Według ustawy o świadczeniach opieki zdrowotnej finansowanej ze środków publicznych do zadań własnych gminy w zakresie zapewnienia równego dostępu do świadczeń opieki zdrowotnej należy w szczególności (art. 7):

1. Opracowywanie i realizacja oraz ocena efektów programów polityki zdrowotnej wynikających z rozpoznanych potrzeb zdrowotnych i stanu zdrowia mieszkańców gminy.

2. Inicjowanie i udział w wytyczaniu kierunków przedsięwzięć lokalnych zmierzających do zaznajamiania mieszkańców z czynnikami szkodliwymi dla zdrowia oraz ich skutkami.

3. Podejmowanie innych działań wynikających z rozeznanych potrzeb zdrowotnych i stanu zdrowia mieszkańców gminy [11].

Do zadań powiatu należy natomiast (art. 8):

1. Opracowywanie i realizacja oraz ocena efektów programów polityki zdrowotnej wynikających z rozpoznanych potrzeb zdrowotnych i stanu zdrowia mieszkańców powiatu po konsultacji z właściwymi terytorialnie gminami.

2. inicjowanie, wspomaganie i monitorowanie działań lokalnej wspólnoty samorządowej w zakresie promocji zdrowia i edukacji zdrowotnej prowadzonych na terenie powiatu.

3. pobudzanie działań na rzecz indywidualnej i zbiorowej odpowiedzialności za zdrowie i na rzecz ochrony zdrowia.

4. podejmowanie innych działań wynikających z rozpoznanych potrzeb zdrowotnych [11].

Od 1 stycznia 2017 r. zniesiono przepis nakazujący przekazywanie powiatowi przez gminę, a marszałkowi województwa przez powiat informacji o realizowanych programach polityki zdrowotnej.

Ustawa o świadczeniach opieki zdrowotnej finansowanej ze środków publicznych przewiduje okres realizacji programu na rok lub wiele lat (art. 48). Ponadto stwarza możliwość dofinansowania (w formie dotacji celowej) programów dotyczących profilaktyki chorób przez gminę i inne jednostki samorządy terytorialnego, nawet gdy są to programy nierealizowane przez te jednostki (art. 48c) [11].

Z kolei w przypadku gdy program realizowany przez gminę i inne jednostki samorządu terytorialnego nie dotyczy świadczeń gwarantowanych, NFZ może przekazać środki na dofinansowanie programów polityki zdrowotnej w wysokości 80\% wszystkich środków przeznaczonych na realizację programu dla jednostki o liczbie mieszkańców nieprzekraczającej 5 tys. i 40\% środków dla pozostałych jednostek [11].

Aby uzyskać dofinansowanie, organ wykonawczy gminy składa wniosek do dyrektora oddziału wojewódzkiego wraz z pozytywną opinią Agencji Oceny Technologii Medycznych i Taryfikacji (AOTiT) oraz pozytywną opinię wojewody dotyczącą zgodności planowanego programu z priorytetami dla regionalnej polityki zdrowotnej oraz zgodności z celami operacyjnymi Narodowego Programu Zdrowia.

Dyrektor oddziału wojewódzkiego NFZ, podejmując decyzję, uwzględnia wpływ planowanych działań na poprawę stanu zdrowia populacji objętej programem oraz możliwości finansowe oddziału (art. 48d) [11].

Program polityki zdrowotnej jest opracowany, wdrażany, realizowany i finansowany przez ministra albo jednostkę samorządu terytorialnego na podstawie map potrzeb zdrowotnych - Map Regionalnych uwzględniających specyfikę potrzeb zdrowotnych społeczności lokalnych i sporządzanych przez właściwego wojewodę w porozumieniu z Wojewódzką Radą do spraw Potrzeb Zdrowotnych oraz Ogólnopolskiej Mapy Potrzeb Zdrowotnych sporządzonej przez Narodowy Instytut Zdrowia Publicznego - Państwowy Zakład Higieny (art. 48a; art. 95a) [11].

Po pozytywnym zaopiniowaniu projektu programu dokonuje się wyboru jego realizatora w drodze konkursu ofert, stosując przepisy kodeksu cywilnego dotyczące przetargu. Jednostka samorządu terytorialnego ogłasza konkurs w swojej siedzibie i na swojej stronie internetowej, co najmniej na $15 \mathrm{dni}$ przed upływem wyznaczonego terminu składania ofert. Ogłoszenie zawiera przedmiot konkursu ofert, wymagania stawiane oferentom niezbędne do realizacji programu polityki zdrowotnej oraz wyznaczony termin i miejsce składania ofert (art. 48b). W myśl ustawy z dnia 15 kwietnia 2011 r. o działalności leczniczej do konkursu mogą przystąpić wszystkie podmioty lecznicze wymienione w art. 4, ust. 1 [11].

\section{OPINIOWANIE PROGRAMÓW POLITYKI ZDROWOTNEJ}

Opiniowaniem projektów programów polityki zdrowotnej zajmuje się AOTMiT. Agencja jest państwową jednostką organizacyjną posiadającą osobowość prawną, nadzorowaną przez ministra zdrowia. Opiniowanie należy do tzw. Rady Przejrzystości, która jest ciałem opiniodawczo-doradczym działającym przy AOTMiT.

Agencja opiniuje projekt w ciągu 2 miesięcy od jego otrzymania. Zasadniczym kryterium oceny programu jest ocena zasadności działań ich skuteczności (ocenia się więc program pod kątem stosowanych technologii medycznych) oraz końcowego efektu (art. 31m; art. 31s). W przypadku gdy programy dotyczą świadczeń gwarantowanych, wymaga się z nimi spójności merytorycznej i organizacyjnej (art. 48) [11].

Przy opiniowaniu projektu programu bierze się pod uwagę i stosuje szereg kryteriów:

1. Wpływ na poprawę zdrowia obywateli przy uwzględnieniu:

a) priorytetów zdrowotnych;

b) wskaźników zapadalności, chorobowości lub śmiertelności określonych na podstawie aktualnej wiedzy medycznej.

2. Skutki następstw choroby lub stanu zdrowia, w szczególności prowadzących do:

a) przedwczesnego zgonu;

b) niezdolności do samodzielnej egzystencji;

c) niezdolności do pracy;

d) przewlekłego cierpienia lub przewlekłej choroby;

e) obniżenia jakości życia. 
3. Znaczenie dla zdrowia obywateli przy uwzględnieniu konieczności:

a) ratowania życia i uzyskania pełnego wyzdrowienia;

b) ratowania życia i uzyskania poprawy stanu zdrowia;

c) zapobiegania przedwczesnemu zgonowi;

d) poprawiania jakości życia bez istotnego wpływu na jego długość.

4. Skuteczność kliniczną i bezpieczeństwo.

5. Stosunek uzyskiwanych korzyści zdrowotnych do ryzyka zdrowotnego.

6. Stosunek kosztów do uzyskiwanych efektów zdrowotnych.

7. Skutki finansowe dla systemu ochrony zdrowia, w tym dla podmiotów zobowiązanych do finansowania świadczeń opieki zdrowotnej ze środków publicznych (art. 31a) [11].

\section{PROGRAM ZAPOBIEGANIA OTYŁOŚCI - ODWAŻNA ÓSEMKA - OGÓLNE ZAŁOŻENIA}

Aktualnie realizowanym przez miasto Szczecin programem polityki zdrowotnej jest „Program Przeciwdziałania nadwadze i otyłości wśród dzieci w wieku 8 lat uczęszczających do szczecińskich szkół podstawowych", który funkcjonuje pod nazwą Program Zapobiegania Otyłości - Odważna Ósemka.

Adresatami programu są wszystkie dzieci 8-letnie uczęszczające do szczecińskich szkół podstawowych (11494) w trzech rocznikach: rocznik 2008 (3939 osób), rocznik 2009 (3792 osoby), rocznik 2010 (3763 osoby). Okres realizacji to lata 2016-2018 (od daty zawarcia umowy do 30 listopada 2018 r.) [14].

Spodziewanym efektem zdrowotnym programu jest wpływ zmiany nawyków w zakresie żywienia i aktywności fizycznej wśród populacji. Działania związane z programem zdrowotnym są skierowane także do rodziców (opiekunów) dzieci.

Deklarowanym celem głównym programu jest poprawa stanu zdrowia uczniów drugiej klasy szkół podstawowych z terenu Szczecina poprzez zmniejszenie ryzyka wystąpienia nadwagi i otyłości oraz innych chorób cywilizacyjnych poprawa stanu zdrowia dzieci z Gminy Miasta Szczecin poprzez przeprowadzenie kompleksowej interwencji edukacyjno-zdrowotnej u dzieci z wykrytymi wybranymi czynnikami chorób cywilizacyjnych oraz stworzenie w środowisku szkolnym warunków sprzyjających właściwym nawykom żywieniowym oraz aktywności fizycznej jako elementów utrzymania i poprawy zdrowia. Program jest finansowany w całości ze środków własnych Gminy Miasto Szczecin. Koszt realizacji programu wynosi $1046000 \mathrm{zł} \mathrm{[14].}$

Konkurs na projekt programu (nr konkursu: WSS-IV.2.2015 WP) ogłoszono w listopadzie 2015 r. Wybrano projekt Polskiego Towarzystwa Programów Zdrowotnych z Gdańska. Po pozytywnym zaopiniowaniu projektu, w lipcu 2016 r. Gmina Miasto Szczecin ogłosiła konkurs na wybór realizatora programu (nr konkursu WSS-IV.3.2016.WP). Oprócz spełnienia warunków formalnych oferenci konkursu mieli obowiązek dostarczyć 2 załączniki w postaci formularza zgłoszeniowego (zawierającego oprócz danych podmiotu leczniczego, m.in. informacje o podmiotach współpracujących, koordynatorze zadania, zakładanych rezultatach realizacji zadania, planowanych działaniach informacyjno-promocyjnych), a także formularza kalkulacji cenowej oraz szczegółów oferty (zawierających m.in. wyszczególnienie liczby specjalistów oraz kosztów jednostkowych).

Wybrano ofertę Samodzielnego Publicznego Szpitala Klinicznego nr 1 im. prof. Tadeusza Sokołowskiego PUM mieszczącego się przy ul. Unii Lubelskiej 1 w Szczecinie.

Realizację celu opisano w sześciu zadaniach:

1. Promocja zdrowego stylu życia.

2. Dostarczenie informacji o dalszym prozdrowotnym postępowaniu (plan postępowania prozdrowotnego).

3. Wczesne wykrycie zaburzeń zdrowotnych.

4. Przeciwdziałanie rozwojowi chorób cywilizacyjnych.

5. Kwalifikacja do etapu specjalistycznego programu (w przypadku ryzyka rozwoju chorób cywilizacyjnych).

6. Opracowanie szczegółowej statystycznej analizy badań do wykorzystania w szkolnych programach wychowania zdrowotnego [15].

Problemy zdrowotne, do których rozwiązania zmierza program, to: przedwczesna umieralność z powodu chorób naczyniowo-sercowych, wysoka zachorowalność na otyłość i cukrzycę oraz zaburzenia rozwoju fizycznego i psychospołecznego dzieci i młodzieży.

Nadwaga i otyłość wśród dzieci są coraz powszechniejszymi problemami cywilizacyjnymi w tzw. krajach rozwiniętych. Problem ten dotyczy już populacji dziecięcej. W Polsce w grupie 9-latków otyłość stwierdzono u 13,2\% dziewcząt oraz u 12,1\% chłopców [9]. Do pomiarów prawidłowej masy ciała służy wskaźnik masy ciała - BMI. Jeżeli wskaźnik wynosi powyżej 25, wówczas występuje nadwaga, natomiast powyżej 30 - otyłość. Nadwaga i otyłość zwiększają ryzyko wystąpienia wielu chorób cywilizacyjnych, m.in. cukrzycy typu 2, nadciśnienia tętniczego, chorób sercowo-naczyniowych, chorób układu kostno-stawowego oraz wad postawy. Wpływ na nadwagę i otyłość mają głównie czynniki związane ze stylem życia - niewłaściwe odżywianie oraz niewystarczająca aktywność fizyczna.

Biuro Światowej Organizacji Zdrowia Regionu Europejskiego wraz z International Centre for Health and Society Universityy College w Londynie opracowało dokument, w którym określiło społeczne uwarunkowania zdrowia i jego implikacje dla polityki zdrowotnej [16]. Wskazano w nim 10 zależnych od siebie czynników społecznych warunkujących zdrowie. Znalazły się w nim m.in. kwestie: odpowiedniego środowiska pracy, ograniczenia złych warunków społeczno-ekonomicznych środowiska życiowego i zjawiska wykluczenia społecznego, ograniczenie alkoholu i wpływu innych substancji psychoaktywnych na życie człowieka, stwarzanie odpowiedniego środowiska we wczesnym dzieciństwie (tryb życia rodziców) i wreszcie dostarczenia bezpiecznej żywności wpływającej na właściwą dietę.

Pomimo dużej podaży żywności i stosunkowo niewysokich cen pojawia się problem niedożywienia i niedoboru żywności pełnowartościowej (warzywa i owoce), przy jednoczesnym nadmiarze żywności wysokoenergetycznej (cukry i tłuszcze) i przetworzonej. Działania zapobiegające problemowi nadwagi 
i otyłości powinny zostać podjęte już we wczesnym wieku dziecięcym i kontynuowane wraz z procesami wzrastania i dojrzewania. Wskazania dotyczące realizowanej polityki zdrowotnej, oprócz odpowiedniej polityki żywieniowej (podaż i dystrybucja zdrowej żywności), dotyczą także czynnika edukacyjnego i zmiany nawyków, które powinny obejmować zarówno dzieci, jak i ich rodziców. Do celów szczegółowych programu należy:

1. Zmniejszenie częstości występowania nadwagi i otyłości u dzieci i młodzieży.

2. Zwiększenie świadomości zdrowotnej dzieci i rodziców (opiekunów).

3. Identyfikacja dzieci z czynnikami ryzyka rozwoju chorób cywilizacyjnych.

4. Identyfikacja dzieci z chorobami metabolicznymi oraz innymi chorobami wymagającymi leczenia w trybie pilnym w ramach świadczeń finansowanych przez NFZ.

5. Wprowadzenie trwałych zmian w stylu życia dotyczących zachowań zdrowotnych.

6. Zmniejszenie ryzyka występowania chorób cywilizacyjnych, w tym głównie cukrzycy typu 2 wśród dzieci objętych programem.

7. Zwiększenie zaangażowania środowiska szkół podstawowych w promocję zdrowego stylu życia i profilaktykę chorób cywilizacyjnych [17].

\section{ETAPY REALIZACJI PROGRAMU}

Realizacja programu odbywa się w dwóch etapach. Etap podstawowy polega na przeprowadzeniu na terenie szkół Szczecina dwóch rodzajów badań. Przesiewowe badania fizykalne obejmują: masę ciała (pomiary antropometryczne i bioimpedancja), ciśnienie tętnicze krwi (pomiary RR), postawę ciała, sprawność krążeniowo-oddechową (Kasch Pulse Recovery Test). Badania sondażowe dotyczą natomiast stanu zdrowia, zachowań zdrowotnych rodziców oraz czynników ryzyka chorób cywilizacyjnych występujących u dzieci. Po zakończeniu etapu podstawowego uczestnicy programu (osoby bez wykrytych nieprawidłowości masy ciała) otrzymują materiały edukacyjne oraz indywidualny plan postępowania zdrowotnego. Grupa z nieprawidłowościami, narażona na ryzyko rozwoju chorób cywilizacyjnych i wyłoniona w wyniku badań, zostaje zakwalifikowana do etapu specjalistycznego, podczas którego dzieci z czynnikami ryzyka chorób cywilizacyjnych oraz ich rodziny zostają objęci roczną opieką przez zespół specjalistów: lekarza, dietetyka (dobór odpowiedniej diety), psychologa (umotywowanie rodziców do zmiany zachowań zdrowotnych) i specjalistę aktywności fizycznej (dostosowanie ćwiczeń fizycznych do rozwoju i możliwości dziecka). Zorganizowane są także warsztaty edukacyjne. Celem interwencji podjętej w drugim etapie jest zmiana nawyków żywieniowych, podjęcie odpowiedniej aktywności fizycznej oraz redukcja masy ciała.

Rada programu ustala dla każdego indywidualny plan postępowania, m.in. poprzez przeprowadzenie kolejnej serii badań (pomiar ciśnienia krwi, poziom glukozy we krwi TSH,
fT4, profil lipidowy, DTOG, insulinemia po DTOG, parametry funkcji wątroby i nerek). W ramach programu będzie też funkcjonować całodobowa platforma internetowa pozwalająca na bieżące konsultacje ze specjalistami.

Kryteriami włączającymi do programu w przypadku szczecińskiego programu są zgoda (pisemne oświadczenie) rodziców lub opiekunów oraz ankieta składająca się 26 pytań. Pytania dotyczą stanu zdrowia i stylu życia dziecka oraz stanu zdrowia rodziców. Wypełnienie ankiety pozwoli na określenie ryzyka wystąpienia otyłości u osób badanych (informacja dla rodziców).

Monitorowaniem programu zajmuje się Rada Programu, a nadzór merytoryczny pełni lekarz specjalista. Kryteriami stosowanymi w monitoringu programu są m.in. liczba uczestników programu, procent uczestników, jaki ukończył program, procent dzieci będących pod obserwacją w ciągu 6 miesięcy i 1. roku od zakończenia programu oraz monitorowanie wskaźników BMI u wszystkich włączonych do programu, na jego początku, na zakończenie oraz po 1. roku od zakończenia. Dla Urzędu Miasta Szczecin zostanie także przygotowane roczne oraz końcowe sprawozdanie merytoryczno-finansowe z realizacji całego programu w formie pisemnej oraz elektronicznej.

Ocena efektywności programu zależy od skuteczności przeprowadzonego monitoringu, a wpływ na nią mają oceny uzyskanych skutków zdrowotnych obejmujących: poprawę wskaźnika BMI, stan samopoczucia dziecka, jego samoocenę, liczbę rodziców z wiedzą dotyczącą zdrowego stylu życia, zmianę zachowań zdrowotnych oraz żywieniowych rodziców i dzieci [14].

\section{OPINIA O PROGRAMIE}

Projekt programu AOTMiT oceniła pozytywnie. Wskazano na trafnie dobrany cel główny (znaczenie i skutki problemu zdrowotnego), a także odpowiednio dobraną populację, czyli wiek wczesnoszkolny (obecnie zaleca się wykonanie badania przesiewowego w kierunku otyłości już u dzieci 6-letnich). Podkreślono spójność celów programu ze spodziewanymi efektami i miernikami efektywności, a także połączenie działań promujących dietę z działaniami promującymi aktywność fizyczną jako istotnych celów. Zwrócono także uwagę na pozytywne aspekty interwencji podejmowanej w drugim etapie programu - kompleksowość (obecność psychologicznych działań behawioralno-poznawczych) oraz multidyscyplinarność zespołu, pod którego opieką pozostają rodziny dzieci zakwalifikowanych do drugiego etapu programu. Podkreślono jednocześnie prawidłowość i częstotliwość stosowanych mierników efektywności (BMI), a także możliwość konsultacji elektronicznych rodziców z prowadzącymi program. W opinii wskazano też na prawidłowość działań w zakresie monitorowania programu, przy czym zalecono rozszerzenie monitorowanych efektów programu: poprawy diety i aktywności fizycznej, redukcji siedzącego trybu życia oraz barier uczestnictwa w programie. Mankamenty, jakie wskazano w opinii, dotyczą niespójności między budżetem 
a liczbą przebadanych osób. Według AOTMiT dostępny budżet pozwala na sfinansowanie badań przesiewowych 7800 dzieci. Zalecono więc wyjaśnienie niespójności. Inna uwaga dotyczyła niewskazania w projekcie metody wyboru realizatora programu, niemniej jednak został on wybrany w prawidłowy sposób w drodze konkursu ogłoszonego przez Prezydenta Miasta Szczecin [18].

\section{PODSUMOWANIE}

Program Zapobiegania Otyłości - Odważna Ósemka jest praktyczną realizacją założeń zawartych w Strategii Rozwiązywania Problemów Społecznych dla Gminy Miasto Szczecin na lata 2015-2020 w obszarze Profilaktyka dla dzieci i udogodnienia dla rodziców. Dotyka coraz powszechniejszego problemu - otyłości i nadwagi wśród dzieci. Szczególnie istotne wydają się aspekty odpowiednio wczesnej interwencji, kompleksowości działań oraz adresowania programu do całych rodzin.

W Strategii Rozwiązywania Problemów Społecznych dla Gminy Miasto Szczecin na lata 2015-2020, wymieniając dotychczasowe działania miasta Szczecin w zakresie ochrony zdrowia, zwrócono uwagę na spadek ilości realizowanych przez miasto działań z zakresu profilaktyki i promocji zdrowia, a także na malejącą liczbę adresatów tych działań. W zakresie realizowanych programów polityki zdrowotnej nastąpił spadek z 11 programów adresowanych do 8666 osób w 2012 r. do 5 programów adresowanych do 1731 osób w 2014 r. [1].

Biorąc pod uwagę ten niekorzystny trend, realizacja programu Odważna Ósemka stanowi istotny krok w kierunku zintensyfikowania działań w zakresie lokalnej polityki zdrowotnej. Podejmuje się również kolejne działania z obszaru Profilaktyka dla dzieci i udogodnienia dla rodziców. Wybrano realizatorów projektów dwóch programów polityki zdrowotnej. Katedra i Klinika Okulistyki Samodzielnego Publicznego Szpitala Klinicznego nr 2 PUM została realizatorem projektu „Wykrywanie wad i schorzeń narządu wzroku wśród uczniów klas II szkół podstawowych" (konkurs nr WSS-IV.1.2017.WP), natomiast Uniwersytecka Klinika Stomatologiczna PUM Sp. z o.o. Poradnia Stomatologii Dziecięcej zrealizuje projekt „Zapobieganie próchnicy wśród dzieci klas VI uczęszczających do szczecińskich szkół podstawowych" (konkurs nr WSS-IV.1.2017.AB). Ogłoszono również konkurs na realizację projektu programu polityki zdrowotnej „Program profilaktyki wad postawy i schorzeń narządu ruchu wśród uczniów klas I szczecińskich szkół podstawowych" (konkurs nr WSS-IV.3.2017.WP) [19].

\section{PIŚMIENNICTWO}

1. Uchwała nr XVI/384/16 Rady Miasta Szczecin z dnia 23 lutego 2016 r. w sprawie przyjęcia Strategii Rozwiązywania Problemów Społecznych dla Gminy Miasto Szczecin na lata 2015-2020 wraz z załącznikiem p. 30-99. http://mopr.szczecin.pl/dokumenty/strategia_rozwiazywania_problemow_spolecznych_dla_gminy_miasto_szczecin_na_lata_2015-2020_15_05_12_11_05_2016.pdf (31.10 2017).

2. Ustawa z dnia 5 czerwca 1998 r. o samorządzie powiatowym. DzU z 2016 r., poz. 814 .

3. Ustawa z dnia 8 marca 1990 r. o samorządzie gminnym. DzU z 2016 r., poz. 446,1579 z późn. zm.

4. Ustawa z dnia 12 marca 2004 r. o pomocy społecznej. DzU z 2013 r., poz. 182 z późn. zm.

5. Krzystek P. Program Szczecin 2020. http://www.szczecin.eu/sites/default/ files/program_szczecin_2020.pdf (31.10.2017).

6. Drugie Porozumienie Programowe dla Szczecina. 8.12.2014. http://www. szczecin.pl/files/25D13E573C19457F8244F93E3F2E0C55/Drugie\%20 Porozumienie \%20Programowe $\% 20$ dla\%20Szczecina.pdf\#page=7\&zoom=auto,-13,729 (31.10.2017).

7. Włodarczyk WC. Współczesna polityka zdrowotna. Wybrane zagadnienia. Warszawa: Wolters Kluwer; 2014. p. 23.

8. Andruszkiewicz A, Banaszkiewicz M. Promocja zdrowia. T. 1. Teoretyczne Podstawy Promocji Zdrowia. Lublin: Czelej; 2008. p. 83-181.

9. Sygit M. Zdrowie Publiczne. Warszawa: Wolters Kluwer; 2010. p. 24-163.

10. KarskiJB. Praktyka i teoria promocji zdrowia. Warszawa: CeDeWu; 2004.p. 24.

11. Ustawa z dnia 27 sierpnia 2004 r. o świadczeniach opieki zdrowotnej finansowanych ze środków publicznych. DzU 2015 r., poz. 581 z późn. zm.

12. Czupryna A, Poździoch S, Ryś A, Włodarczyk C. Zdrowie publiczne. Kraków: Vesalius; 2000. p. 29-30.

13. Ustawa z dnia 15 kwietnia 2011 r. o działalności leczniczej. DzU z 2015 r., poz. 618 z późn. zm.

14. Szczegółowe warunki do ogłoszenia o konkursie nr WSS-IV.3.2016.WP na realizację zadania pn. „Przeciwdziałanie nadwadze i otyłości wśród dzieci w wieku 8 lat uczęszczających do szczecińskich szkół podstawowych”. Załącznik nr 1. Biuletyn Informacji Publicznej Urzędu Miasta Szczecin; 2016.

15. Informacja dla Rodziców. Odważna Ósemka! Program zapobiegania otyłości u dzieci. Miasto Szczecin, SPSK. https://pe.szczecin.pl/files/F63DDDE235A347DDA61AF6AC757DF519/Informacja_dla_rodzicow_odwazna_osemka__program_zapobiegania_otylosci_u_dzieci.pdf (31.10.2017).

16. Karski JB. Polityka zdrowotna samorządu terytorialnego. Warszawa: CeDeWu; 2012. p. 85.

17. Przeciwdziałanie nadwadze i otyłości wśród dzieci w wieku 8 lat. SPSK1 PUM; 2016. https://spsk1.szn.pl/o-szpitalu/programy-medyczne/ przeciwdzialanie-nadwadze-i-otylosci-wsrod-dzieci-w-wieku-8-lat (31.10.2017).

18. Opinia Prezesa Agencji Oceny Technologii Medycznych i Taryfikacji nr 36/2016 z dnia 4 marca 2016 r. o projekcie programu polityki zdrowotnej pn. „Przeciwdziałanie nadwadze i otyłości wśród dzieci w wieku 8 lat uczęszczających do szczecińskich szkół podstawowych”. Agencja Oceny Technologii Medycznych i Taryfikacji; 2016. www.aotm.gov.pl/ assets/files/Opinie-sam_pr_zdr/2016/OP-036-2016.pdf (31.10.2017).

19. Wyniki konkursów ofert Wydziału Spraw Społecznych. Nr konkursu: WSS-IV.3.2017.WP. Konkurs ofert na projekt programu profilaktyki zdrowotnej pn. „Program profilaktyki wad postawy i schorzeń narządu ruchu wśród uczniów klas I szczecińskich szkół podstawowych”. Biuletyn Informacji Publicznej Urzędu Miasta Szczecin; 2017. http://bip.um.szczecin.pl/chapter_50222.asp?soid=F9B28303DC104B0E9E08F9F915463F22 (31.10.2017). 